\title{
ZARAZNE BOLESTI U HERCEGOVINI U DOBA TURSKE VLADAVINE
}

\author{
Robert JOLIĆ \\ Župni ured Klobuk \\ $\mathrm{BiH}-88324$ Klobuk \\ E-pošta: rjolic@tel.net.ba
}

\author{
UDK 616.9(497.6-3 Hercegovina) \\ "17/18"(093) \\ 314.424:616.9]"17/18" \\ Izvorni znanstveni rad \\ Primljeno: 29. travnja 2015 \\ Prihvaćeno: 9. svibnja 2015
}

\section{Sažetak}

Uz brojne nedaće koje su svakodnevno sustizale katolike u Hercegovini, $s$ vremena na vrijeme dolazile su i zarazne bolesti protiv kojih u ono vrijeme nije bilo nikakva lijeka te su uzimale brojne ljudske živote, a neke su, osobito kuga, prerastale i u prave epidemije, dok bi se ona iz 1814.-1818. godine mogla označiti i kao pandemija. Autor na temelju ljetopisa i drugih izvora, a u prvome redu sačuvanih matičnih knjiga katoličkih župa iz turskoga razdoblja, nastoji rekonstruirati učestalost, snagu i dužinu trajanja pojedinih zaraznih bolesti u zapadnoj Hercegovini, prije svega kuge, a potom i kolere i velikih boginja, kao i nekih drugih zaraznih bolesti. Veliki je nedostatak za zaokruženje slike o navedenoj temi gubitak brojnih matičnih knjiga, tako da za neka hercegovačka područja postoje tek manjkave naznake o raširenosti i dužini trajanja pojedinih zaraza, a za druga čak niti to.

Ključne riječi: Hercegovina, matične knjige (umrlih), zarazne bolesti, kuga, boginje (variole), kolera, dizenterija, ospice. 


\section{Uvod}

Atomska bomba staroga svijeta zvala se - kuga. Ona je brisala čitave obitelji, gotovo čitava sela i gradove, pojavljivala se iznenada, trajala različitim intenzitetima koliko joj se prohtjelo i obično završavala kako je i započela - iznenada, bez ikakva logična objašnjenja. Nije se mogla liječiti pa tako niti kontrolirati. Jedino je rješenje bilo pobjeći što dalje od žarišta kuge i ne imati nikakva dodira s njom, ili pak hermetički zatvoriti granice određenih područja, primjerice državne granice, kako se ne bi mogla prenijeti iz zaraženih mjesta. Ljudi su nerijetko bježali glavom bez obzira, u šume i pećine, daleko od naseljenih mjesta, ali su onda redovito plaćali cijenu nečemu drugom - gladi, koja je bila redovita pratilja kuge. Polja su naime ostajala neobrađena, ili se pak nitko nije usuđivao ubirati plodove $s$ obrađenih površina pa je glad nastupala kao logična posljedica bijega u zabitna mjesta u kojima hrane nije bilo dovoljno ili je nije bilo uopće. Danas je uistinu nemoguće i zamisliti sav užas i strah koji su podnosili stanovnici zaraženih područja: desetine, stotine, tisuće umirale su u istome danu, a lijeka i pomoći nije bilo. Pokojnike se pokopavalo i iz pijeteta prema njima, ali još više da se zaraza ne bi širila dalje. Nije rijedak slučaj da ih nije imao tko pokopati pa su se njima hranili psi ili divlje životinje. Zbog velikih poteškoća u prijenosu do grobalja brojni su pokopavani na mjestu gdje su preminuli ili najbliže tome mjestu, u ogradama, vrtačama, šumama... Tako su nastajala brojna nova improvizirana groblja, o kojima spomen postoji do danas, a neki se lokaliteti do danas nazivaju "kužna groblja". Mrtvace su kačili različitim kukama kako ih ne bi dodirivali rukama i tako prenosili do groba. Opće je mišljenje bilo da se kuga prenosi zrakom, iako to zapravo nije točno: ona se prenosi u kapljicama kašlja koji iskašlje bolesnik ili još češće $s$ buha koje su inficirane živeći na glodavcima (najčešće štakorima), od kojih zapravo ta bolest i potječe. ${ }^{1}$ U uvjetima u kakvima su živjeli ljudi u našim krajevima u tursko doba, bez ikakve higijene i zaštite, ne treba ni najmanje čuditi da je kuga, kao i druge zarazne bolesti, lako hvatala korijena i nesmetano se širila. U sačuvanim kronikama i izvješćima kuga se predstavlja u apokaliptičnim slikama, kao Smrt s kosom u ruci ispred koje ne ostaje ništa na uzgoru, ili kao apokaliptični jahači koji uništavaju sve pred sobom. Koliko je kuga utjecala na samu svijest ljudi koji su je proživjeli (i preživjeli) možda ponajbolje svjedoči činjenica da su se godine računale prema njoj, točnije od njezina svršetka. Tako primjerice još krajem 19. stoljeća fra Martin Mikulić bilježi riječi jednoga 90-godišnjega starca koji je upamtio najrazorniju kugu u povijesti na našim prostorima, onu od 1814./1815. do 1817./1818. godine; opisujući "utvički rat" iz 1832. kaže da je "bio u proljeće o kopanju kukuruza petnaeste godine po kugi".2 Ta se kuga dakle tako snažno usjekla u sjećanje ljudi da su još i 70 godina nakon nje vrijeme računali po njoj!

1 http://hr.wikipedia.org/wiki/Kuga (22. 4. 2015.).

2 Martin Mikulić, Pustinjakove pripovijetke iz seoskog života zapadne Hercegovine, Ivan Alilović (prir.), Duvno, 1972., str. 40. 
$\mathrm{Na}$ temelju sačuvanih izvješća, ali prije svega na temelju matičnih knjiga, ovdje želimo prikazati kakvo je bilo stanje u zapadnom dijelu Hercegovine vezano za zarazne bolesti, a prije svega za kugu koja je svakako bila najsmrtonosnija od svih. Velika je poteškoća i šteta što u većini župa nisu sačuvani najstariji svesci matica umrlih pa tako ne ćemo uspjeti saznati niti podatke za bolesti starije od 18., pa čak u najvećem broju slučajeva niti 19. stoljeća.

Donosimo najprije opće podatke o kugi kroz povijest, s osobitim naglaskom na prostore Hercegovine i susjednih područja, prije svega Dalmacije i Bosne, a potom sve raspoložive podatke koje smo uspjeli povaditi iz sačuvanih matičnih knjiga na području današnje Mostarsko-duvanjske biskupije, vezane dakako za katolike jer su u crkvene matice upisivani podatci isključivo za katolike. Svrha je rada pokazati u kakvim su teškim, danas gotovo nezamislivim uvjetima živjeli katolici, pa i općenito stanovnici naših prostora u tursko doba, a zapravo sve do druge polovice 20 . stoljeća, dok se nisu otkrila cjepiva za većinu zaraznih bolesti staroga svijeta. Ponekad izgleda gotovo nevjerojatno da se život ovdje uopće održao, a pogotovo ako se ima na umu da su u tursko doba osobito katolici bili izloženi trajnim progonima od turskih vlasti i silnika, da su živjeli u trajnoj bijedi, nerijetko na rubu gladi, da su redovito umirali veoma mladi, a gotovo svako drugo dijete nije do- živjelo deset godina života, te da su $\mathrm{k}$ tome svako malo bili izloženi i razornim pohodima kuge, kolere ili variola. Spašavao ih je isključivo visoki natalitet koji je uspijevao nadoknaditi sve te silne gubitke koji nikada nisu prestajali.

\section{Kuga u svijetu i u Bosni i Hercegovini}

Zapisi o kugi pojavljuju se već u starom svijetu, ali nije sigurno da je riječ o bubonskoj kugi, dakle kugi u današnjem smislu riječi. Naime, i u grčkom i u latinskom jeziku riječ kuga (lat. pestis) znači općenito svaku zaraznu bolest. Tako se prvi zapis o kugi pojavljuje već u staroegipatskom medicinskom spisu (tzv. Ebersov papirus) starom oko 3500 godina, u biblijskim tekstovima, kao i u djelima grčkih povjesničara. ${ }^{3}$ Osobito je dojmljiv opis Atenske kuge iz pera povjesničara Tukidida. Riječ je o zaraznoj bolesti (vjerojatno trbušnom tifusu) koja je 430. godine pr. Kr. pobila oko 30.000 Atenjana, među kojima i velikoga atenskog državnika i vojskovođu Perikla. Bilo je to u vrijeme spartanske opsade Atene, a bolest je došla iz Etiopije, iz koje se proširila na Egipat, Libiju i Atenu. ${ }^{4}$ Osobito je poznata velika kuga zvana Justinijanova, po bizantskom caru Justinijanu, koja je zahvatila i poharala Bizantsko Carstvo, a potom i ostatak svijeta, 541.542. godine. Carski kroničar Prokopije iz Cezareje ostavio je izvrstan opis te bolesti i njezinih učinaka. $\mathrm{Na}$

3 Damir TAdić, "(Prigodom 200. obljetnice epidemije kuge u livanjskom kraju 1814.1818.): Apokaliptična pandemija", u: Kalendar svetog Ante 2015, Sarajevo, 2014., str. $180-181$.

4 http://hr.wikipedia.org/wiki/Atenska kuga (22. 4. 2015.). 
vrhuncu epidemije, prema Prokopijevim vijestima, u samom Carigradu umiralo je dnevno 10.000 ljudi, dok suvremeni povjesničari misle da je prije riječ o 5000 žrtava dnevno. Kuga je došla iz Egipta ili Etiopije, i to brodovima koji su prevozili žito u Carigrad. Sa žitom su međutim dovozili i zaražene štakore koji su zarazili grad. Iz Carigrada se epidemija proširila po cijeloj Europi, sve do Irske i Danske, po sjevernoj Africi, Bliskom istoku, Perziji i južnoj Aziji. Smatra se da je kuga ubila čak $40 \%$ stanovnika Carigrada, kao i četvrtinu stanovnika Bizantskoga Carstva. Riječ je o milijunima žrtava. Političke i ekonomske posljedice bile su nesagledive. Misli se da je kuga u svojim smrtonosnim pohodima, počev od Justinijanove pa kroza stoljeća koja slijede, ubila više od 100 milijuna ljudi. Taj broj neki povjesničari, kao Josiah C. Russell, još više povećavaju smatrajući kako je europska populacija od kuge izgubila čak 50-60\% stanovnika. Justinijanova kuga zadnja je pandemija klasičnoga razdoblja, a za novu će trebati čekati punih 900 godina, sve do pojave Crne smrti sredinom 14 . stoljeća. ${ }^{5}$ Ta pandemija koja je zahvatila Europu počev od 1348. godine, prvotno je bila nazvana Velika smrt, a mnogo kasnije, u 18. st., dobila je do danas uobičajen naziv Crna smrt ili Crna kuga. Došla je iz jugozapadne Azije i proširila se postupno po čitavoj Europi. Vjeruje se da je ista bolest u Europi izbijala u svakoj novoj generaciji te, $s$ prekidima i u različitim intenzitetima, trajala sve do pred kraj 18. stoljeća, dakle preko 400 godina.
Tijekom 17. i 18. stoljeća osobito su strašne bile Talijanska kuga (1629.1631.), Velika londonska kuga (1665.1666.), Velika bečka kuga (1679.), Velika marseillska kuga (1720.-1722.) i kuga u Moskvi (1771.). Pretpostavlja se da je ta pandemija tijekom 400 godina usmrtila oko 75 milijuna ljudi, odnosno oko polovice tadašnjega stanovništva Europe. Bolest karakteriziraju buboni (povećani limfni čvorovi), uzrokuje je bacil Yersinia pestis a prenose insekti, primjerice buhe, koje su se zarazile na koži uzročnika bolesti glodavaca, prije svega crnoga štakora. Zaražene osobe umirale su u roku od dva ili više dana. ${ }^{6}$

Ne shvaćajući niti uzroke bolesti niti njezina širenja i u nemogućnosti bilo kakve obrane, a gledajući svakodnevno desetine i stotine nepokopanih mrtvaca po ulicama, ljudi srednjega vijeka kugu su tumačili kao kaznu Božju za grijehe pred nadolazeći sudnji dan. K tome su u njoj, ma koliko to bilo morbidno, gledali i neke vrste ispravljanja zemaljskih nepravdi i nejednakosti jer je pogađala jednako i bogate i siromašne, kraljeve, plemstvo i kmetove, umne i priproste. Zbog toga je u likovnoj umjetnosti nastao novi simbolički prikaz nazvan $\mathrm{mr}$ tvački ples, povorka mrtvaca ili ples mrtvaca (franc. danse macabre). Riječ je o freskama koje prikazuju kosture u plesu s predstavnicima različitih društvenih slojeva: kraljeva, plemića, svećenika, seljaka, djece, razbojnika. Svi su oni združeni u plesu koji vodi Smrti, jer Smrt ne haje za društveni položaj, spol, bogatstvo ili dob ljudi. 
U nedostatku bilo kakvih lijekova ljudi se obraćaju svecima za pomoć, a osobito sv. Roku. Prilikom blagoslova polja sve do danas ostao je zaziv: "Od kuge, glada, rata i zle godine, oslobodi nas, Gospodine!"7

Kako je, primjerice, izgledala Crna kuga u Splitu, koja se počela širiti na Božić 1348., opisao je splitski kroničar A. Cutheis. "Kroničar ne donosi nikakve podatke o broju preminulih, ali slikovito opisuje sav užas koji je zahvatio grad. Prema srednjovjekovnom shvaćanju kroničar pomor izazvan kugom prikazuje kao posljedicu 'mnogih i različitih zločina ljudi, koje su počinili protiv Boga'. Njegov opis je apokaliptičan. Navodi kako su pomoru prethodili zatamnjenje Sunca i Mjeseca, potresi i padanje zvijezda s neba te pojava olujnih vjetrova što je tipična apokaliptična ikonografija. Također, sliku općeg beznađa i očaja dočarava simboličkim spominjanjima divljih čopora izgladnjelih vukova koji zavijaju oko gradskih zidina kao demoni, napadaju ljude te izvlače i jedu mrtvace iz grobova; zatim gavranove koji graktaju nad gradom i šišmiše. Sve to stvara sliku jeze i dramatike koja više poetski, negoli činjenično opisuje epidemiju kuge u gradu."8

Kuga se dakle u dalmatinske priobalne gradove prenosila trgovačkim putovima iz zaraženih žarišta. Odatle se širila i u zaleđe, pa tako i u Her- cegovinu i Bosnu, ali o tome nema dovoljno sačuvanih podataka, pogotovo za razdoblje srednjega vijeka. Prve vijesti sačuvane su u kronikama bosanskih franjevaca tek iz turskoga razdoblja, u najvećoj mjeri počevši od 17. stoljeća. Upravo se iz njihovih zapisa može vidjeti i sav očaj i strahote koje su vladale u vrijeme kuge. Nastavljač ljetopisa fra Marijana Bogdanovića godine 1816. kugu naziva "bičem" te moli Boga da "ovaj bič od nas odstupi; ukaži svoje milosrđe svrhu nas, Bože naš!",9 a biskup fra Augustin Miletić piše 1817. godine: "Strašni bič kužni još nas u strahu drži i često se sad na jednom sad na drugom kraju po ovoj državi javlja."10 Damir Tadić istražio je da se veći pomori kuge u livanjskom kraju spominju 1532., 1584., 1611., 1615., 1649., 1663., 1670., 1730., 1732., 1743., 1763., 1783., 1795. i 1814.-1818. godine. ${ }^{11}$ Tako bi moglo biti i za ostale dijelove Bosne, pa i Hercegovine, ali o tome je premalo sačuvanih podata$\mathrm{ka}$, a pogotovo iscrpnih. Zanimljivo svjedočanstvo o kugama koje su harale u Livnu u 18. i na početku 19. stoljeća ostavio je svećenik glagoljaš don Jozo Ivković: "Poče kuga velika na 26 listopada 1730 i ova kuga morila je godina 13 . Druga kuga mala počela je moriti na 20 juna 1763 . Treća poče moriti kuga na 8 augusta 1783. Četvrta kuga poče moriti na 1 decibra na 1785 . Opet peta poče moriti po Mostaru na 1813 na 10 deci-

7 D. TADIĆ, "Apokaliptična pandemija", str. 182.

8 http://hr.wikipedia.org/wiki/Kuga u Splitu (22. 4. 2015.).

9 Marijan Bogdanović, Ljetopis kreševskog samostana (1765-1817), Ignacije Gavran (prir.), Sarajevo, 1984., str. 214-216.

10 Julijan Jelenić, Spomenici kulturnoga rada franjevaca Bosne Srebreničke, Mostar, 1927. str. 315. 
bra i kadija iz Mostara donese kugu u Livno i morila je četiri godine dana. I ja dom Jozo bijo sam kapelanom u Vidošim i služio od iste kuge i podnijo velik stra od biča Božjega."12 Neki svećenici i sami su platili životom svoje služenje bolesnika koje su opremali svetim sakramentima prije smrti. Tako je ljetopisac zabilježio da je u studenom 1732. u Duvnu preminuo fra Ludovik Miletić, duvanjski kapelan, rodom iz Fojnice: "Zašto ktijući se nać kod svakog kužnika i svakog pomoć kakono pravi pastir, najposli se i on otrova." ${ }^{13}$

Strašne vijesti o kugi koja je harala Bosnom 1690. godine zapisao je fra Stipan Margitić: "Kud god bi se makô, ležahu mrtvaci: nit se kopahu, nit imadijaše tko. Ljudi jiđahu resu liskovu, s drvja koru, vinovu lozu, pse, mačke. U Sarajevu izidoše dica mater mrtvu; u Banjoj Luci, koga bi obisili, obnoć bi ga gladni ljudi svega izili."14 Spomenutu kugu u godini 1732. zabilježio je drugi ljetopisac: "Ove se godine otrova sva Bosna od kuge; a počela je u Sarajevu i u Jajcu još godine prošaste to jest 1731."15 Kuga je već 1731. iz Bosne dospjela i u Dalmaciju, pa i u Split. ${ }^{16}$ Ljetopisac završava o posljedicama kuge: "Sto od ove kuge pomr, mučno je znat broj. Ovo znam da u velikih mistî kakono u Sarajevu, Mostaru, Banjoj Luci... na dan bi se po trista mrtaca kopalo. I u svoj Bosni nit osta grad, varoš, ni selo, gdi ne pomori." ${ }^{17}$ Ova je kuga s prekidima trajala deset godina, a neko je vrijeme pomor bio upravo strašan. ${ }^{18}$ Nova se velika kuga raširila 1782. iz Sarajeva po čitavoj Bosni i Hercegovini, i opet stigla u Dalmaciju, preko granice, sve do Splita. Ljetopisac fra Jako Baltić zapisao je da se kuga raznijela po svoj Bosni i učinila strašan pomor. Nastavlja: "Zatim kuga kojoj nadiše [ime] oganj, po gradovim, osobito kod Turaka naglo moriaše." Sljedeće je godine izišla iz gradova te počela moriti po svoj Bosni. U Bosni je od kuge umrlo preko 20.000 katolika, a pravoslavnih, muslimana i Židova oko 100.000. Do zime se kuga smirila. Godina je bila plodna, ali zbog kuge nije imao "tko žeti i hranu kupiti" pa je puno žita i ljetine ostalo na poljima. ${ }^{19}$ Kuga je stigla i u Dalmaciju. Godine 1794. strahovito je harala u Splitu. Prenijeli su je useljenici iz Dalmacije koji su došli u Bosnu 1782. jer je te godine vladala velika glad u Dalmaciji. Nakon izbijanja kuge u Bosni bježe natrag u Dalmaciju i pre-

11 D. TADIĆ, "Apokaliptična pandemija", str. 183.

12 Navod prema D. TADIĆ, "Apokaliptična pandemija", str. 184.

13 Nikola Lašvanin, Ljetopis, Sarajevo, 1981., str. 173.

14 Iz Margitićeva rukopisa prepisao N. LAŠvanin, Ljetopis, str. 164-165.

15 Bono Benić, Ljetopis sutješkog samostana, Sarajevo, 1979., str. 115.

16 Stipan Zlatović, Franovci države Presv. Odkupitelja i hrvatski puk u Dalmaciji, Zagreb, 1888., str. 221, 227, 229.

17 N. Lašvanin, Ljetopis, str. 173.

18 Historija naroda Jugoslavije, II., Zagreb, 1959., str. 1324.

19 Jако BALtić, Godišnjak od dogadaja crkvenih, svjetskih i promine vrimena u Bosni, Sarajevo, 1991., str. 61-63; Mijo V. Batinić, Djelovanje franjevaca u Bosni i Hercegovini za prvih šest viekova njihova boravka, III., Zagreb, 1887., str. 151. 
nose epidemiju. ${ }^{20}$ Kuga se u manjoj mjeri pojavila i 1796 . godine. ${ }^{21}$

I onda konačno najveća ikad zabilježena kuga, iz 1814. godine! U nekim bosanskim mjestima počela je harati već u ljeto 1813.: u Travniku, Jajcu, Kotor Varošu i po bosanskoj Krajini. Onda se pritajila do ljeta 1814., kada je zahvatila čitavu Bosnu i proširila se i u Hercegovinu. Širila se strahovitom brzinom, a ljudi su živjeli tek koji dan: neki su umirali isti dan kad su bili zaraženi. Postoji podatak da je u ljeto 1814. u Mostaru u samo tri dana pomorila 3000 osoba. U jajačkom je kraju od kuge umrlo preko 2000 katolika, a u travničkome čak oko 4000. ${ }^{22}$ U Bosni je 1806. bio 114.391 katolik. Nakon završetka kuge, prema popisu iz 1818. godine, taj se broj smanjio na 50.928 duša, što znači da je kuga pomorila više od polovice bosanskohercegovačkih katolika. "Uz kugu se pridruži još nemili gost - glad, od koga skapavaše siromašni narod, koji sada poče bježati po šumama, da se uzčuva od okuženih."23 "Natjerani glađu ljudi se vraćaju u zakužene krajeve i stradaju - bježeći od jedne nevolje postaju žrtve druge." ${ }^{24}$ Upravo je ova posljednja kuga evidentirana i u sačuvanim hercegovačkim matičnim knjigama, od kojih su do danas iz toga razdoblja sačuvane na žalost samo dvije: broćanska i veljačka ili ljubuška. A podatke o onoj iz 1782. donosi samo jedna sačuvana iz toga razdoblja: broćanska.

\section{Matice umrlih i podatci koje nude}

Fra Petar Bakula u svome poznatom Šematizmu iz 1867. zapisao je da većina hercegovačkih župa ima veoma stare matice, uglavnom iz sredine 18. stoljeća. Tako je župa Blato (kasnije Široki Brijeg) imala matične knjige od 1753. godine, Mostar (sa sjedištem u Mostarskom Gracu) od 1748., Gradnići od 1775., Roško Polje od 1773., Posušje od 1736., Ružići od 1778., Veljaci od 1785. Pritom napominje da su neke župe imale i starije matice, ali su one stradale, uglavnom u požaru župnih kuća. Primjerice župa Blato "radi požara kuće, ili kakva drugoga nama nepoznatog uzroka (...) ima matice tek od godine 1753.", župa Brotnjo: "Zbog ponovljenih požara kuće ova župa ima župske matice samo od g. 1775." ili župa Roško Polje: "Ona je jedna od najstarijih župa u Hercegovini, ali zbog požara stare kuće nema matice nego od god. 1773."25 Iako njegovi podatci nisu posve ispravni, ${ }^{26}$

20 SrećKo M. DžAJA, Katolici u Bosni i zapadnoj Hercegovini na prijelazu iz 18. u 19. stoljeće. Doba fra Grge Ilijića Varešanina (1783-1813), Zagreb, 1971., str. 100-101.

21 M. Bogdanović, Ljetopis kreševskog samostana, str. 185. Usp. Ignacij Strukić, Povjestničke crtice Kreševa i franjevačkoga samostana, Sarajevo, 1899. (pretisak 1997.), str. 93.

22 S. M. Džaja, Katolici u Bosni i zapadnoj Hercegovini, str. 101-102.

23 I. Strunkić, Povjestničke crtice Kreševa i franjevačkoga samostana, str. 102; M. V. Batinić, Djelovanje franjevaca, III., str. 190-191.

24 S. M. Džaja, Katolici u Bosni i zapadnoj Hercegovini, str. 102.

25 Petar Bakula, Hercegovina prije sto godina ili Šematizam fra Petra Bakule (iz 1867.), s latinskoga preveo V. Kosir, Mostar, 1970., str. 68, 75, 90, 141, 150, 154.

26 Primjerice, župa Roško Polje ima do danas sačuvanu Maticu umrlih od 1758. i Maticu krštenih od 1763. godine (Robert Jolić - Marko Jukić, Župa Roško Polje. Spomen 
ipak su više nego znakoviti: matične knjige bilo je veoma teško sačuvati $\mathrm{u}$ iznimno turbulentnim vremenima i tragičnim uvjetima u kojima su živjeli župnici i katolici općenito. Ipak, bila bi neizreciva sreća da su do danas sačuvane barem one matice koje su postojale u Bakulino vrijeme. $\mathrm{Na}$ žalost, brojne su od njih kasnije uništene, pogotovo otkako su ih oduzele komunističke vlasti počevši od 1946. godine, najviše zbog nemara i loših uvjeta u kojima su čuvane. Za neke od njih se do danas ne može sa sigurnošću utvrditi gdje su završile, jesu li uništene zauvijek ili su pak otuđene i zaboravljene (nedavni slučaj s početka 2015. godine, kada smo saznali za najstariju sačuvanu Maticu krštenih župe Ružići na mjestu kojega se nitko nikada ne bi dosjetio i vraćanje pravome vlasniku govori dovoljno sam za sebe!).

Bilo kako bilo, za izradbu ovoga rada korištene su sljedeće matične knjige (riječ je dakako isključivo o maticama umrlih jer u drugima sigurno ne bismo pronašli bilo kakav podatak o kugi ili drugim zaraznim bolestima):

župa Brotnjo (Gradnići): sv. I. (1775.1813.), sv. II. (1814.-1838.), sv. III. (1838.-1888.)

župa Veljaci (Ljubuški): sv. I. (1809.1866.); sv. II. (1867.-1893.) župa Mostar (M. Gradac): sv. II. (1832.-1912.)

župa Mostar (od podjele župe 1849. godine): sv. I. (1849.-1896.)

župa Ružići: sv. I. (1839.-1893.)

župa Gorica-Sovići: sv. I. (1839.1908.)

župa Zaslivlje (Konjic): sv. I. (1837.1892.)

župa Duvno (Seonica): sv. I. (1821.1901.); sve starije matice izgorjele su u požaru župne kuće u Seonici 1821. godine $^{27}$

župa Rakitno: sv. I. (1850.-1896.); riječ je o prijepisu izvornika, i to na temelju prijepisa knjiga iz Matičnoga ureda; do danas je nepoznato gdje su izvornici starijih matica, iako postoje naznake da su one još na početku 1964. vraćene župnom uredu. ${ }^{28}$

Najstarija matica umrlih na području današnje Mostarsko-duvanjske biskupije jest ona župe Roško Polje, od 1758. do 1765. godine. Ona je prepisana u računalo, ali svećenici nisu uopće upisivali uzrok smrti, tako da nam u tom smislu ne može biti od koristi. ${ }^{29}$ Najstariji svezak Matice umrlih župe Posušje počinje tek od 1928. godine, pa je za ova istraživanja navedena matica posve neuporabljiva. Matične knjige župe Široki Brijeg

knjiga prigodom 250. obljetnice obnove župe (1758.-2008.), Tomislavgrad, 2008., str. 17). To znači da nije bilo nikakva požara 1773 . godine!

27 Robert Jolić, Život i smrt u Duvnu. Demografska kretanja u Duvnu od 18. do 20. stoljeća na temelju crkvenih matičnih knjiga, Tomislavgrad, 2005., str. 26.

28 Robert Jolić, Šmatizam Hercegovačke franjevačke provincije 2012. godine, Mostar, 2012., str. 201-202.

29 R. Jolić - M. Jukić, Župa Roško Polje, str. 17. Restaurirani izvornik čuva se u Arhivu Hercegovačke franjevačke provincije u Mostaru. Postoji i računalni prijepis navedene matice. 
uništili su partizani početkom 1947. godine, tako da danas župa posjeduje matice tek od 1949. (te preslike matica od 1918. godine), pa su također za ova istraživanja potpuno neuporabljive. ${ }^{30}$ Srećom dvojica su autora prije Drugoga svjetskog rata, dok matice još nisu bile uništene, koristila podatke iz nekih od njih, i to upravo vezano za kugu, tako da ćemo se i u ovome radu moći pomoći njihovim izvodima. Riječ je o župama Mostar i Široki Brijeg, a priloge su objavili dr. fra Leo Petrović i vjerojatno prof. fra Vojislav Mikulić. ${ }^{31}$

\section{Zarazne bolesti zabilježene u matičnim knjigama}

\subsection{Kuga 1783./1784. godine}

Prva kuga koja je zabilježena u sačuvanim matičnim knjigama u zapadnom dijelu Hercegovine jest ona koja je započela u kolovozu 1783. i prestala početkom siječnja sljedeće godine, a i ona samo u maticama župe Brotnjo, jer matice ni jedne druge hercegovačke župe iz toga vremena nisu sačuvane. Kuga je započela u Sarajevu, ali se ubrzo proširila na čitavu Bosnu i Hercegovinu, pa onda i u Dalmaciju. Od nje je u Bosni i Hercegovini umrlo oko 20.000 katolika, a ostalih vjera oko 100.000. Prvi slučaj u Brotnju zabilježen je 11. kolovoza 1783., kada je preminuo 25-godišnji mladić Ilija Filipović. Najviše je osoba preminulo od kuge u prosincu iste godine, i to od dvogodišnje djece do 80-godišnjih staraca. Posljednji su ubilježeni u siječnju 1784. U župi su upisane 62 osobe umrle od kuge (a peste), od čega najveći broj (59) tijekom samo dva mjeseca, od studenoga 1783. do početka siječnja 1784 . U to vrijeme župnici u maticu umrlih još uvijek nisu upisivali niti sela u kojima su živjeli pokojnici niti groblja u koja su se pokopavali pa tako ne možemo znati niti u kojim je selima kuga bila najraširenija, a u kojima je možda nije ni bilo. Znamo samo prezimena onih koji su stradali: Bencunović, Zovković, Buntić, Praščević, Paradžik, Odobašić, a u manjoj mjeri i Filipović, Ljoljić, Arbanasin, Smoljanović. ${ }^{32}$

$\mathrm{Na}$ žalost, ni jedan od navedenih autora koji su imali u rukama matice župa Mostar (sa sjedištem u M. Gracu) i (Mostarsko) Blato (kasnije Široki Brijeg) nisu dali gotovo nikakva podatka o navedenoj kugi, a mi danas to ne možemo ispraviti ili dopuniti jer su matice u međuvremenu nestale. V. Mikulić tako uopće niti ne spominje navedenu kugu, dok L. Petrović tek navodi da je harala i u mostarskoj župi. Uz nju spominje i prijašnje kuge iz 1745 . i 1765 . te onu kasniju, koju detaljnije obrađuje, iz 1814./1815. godine. Navodi samo da

30 R. Jolić, Šematizam... 2012. godine, str. 190, 227.

31 Leo Petrović, "Katoličko stanovništvo u Mostaru", u: (Napredak) Hrvatski narodni kalendar 1937, Sarajevo, 1936., str. 120-132; ve-em [Vojislav Mikulić], "Kuga u mostarskoj župi godine 1814-15", u: Kršćanska obitelj, br. 4/1944., str. 54-56; [IsTI], "Kuga u širokobrieškoj župi godine 1814-15.", u: Kršćanska obitelj, br. 7/1944., str. 105-106.

32 Robert Jolić, Stanovništvo Brotnja u tursko doba, Čitluk - Tomislavgrad, 2009., str. 288-289; usp. Istı, "Kuga i kužna groblja u međugorskoj župi", u: Oaza mira, br. 2, Međugorje, 2014., str. 23. 
je 1765. od kuge u župi umrlo 340 osoba, dok za kugu iz 1783. ne navodi niti toliko. Ispravno zaključuje da su glavni razlog opadanja stanovništva tijekom turskih stoljeća bile "onodobne loše zdravstvene prilike, radi čega su se pojavljivale razne pošasti, najčešće kuga i kolera, mnogo puta i kruta glad (...) kao posljedica bolesti". ${ }^{33}$

Silna je šteta što ni u jednoj župi u Hercegovini nisu sačuvane matice iz 18. stoljeća, osim župe Brotnjo, kao i to što autori koji su imali u rukama te matice prije uništenja nisu iz njih izvukli detaljnije obavijesti, ne samo o kugi, nego i o drugim segmentima života koji su se mogli iščitati iz matičnih knjiga.

\subsection{Kuga 1814.-1818. godine}

Neusporedivo više podataka imamo o ovoj kugi koja je harala nekoliko godina, kako na temelju sačuvanih matica, tako na temelju pisanja dvojice navedenih autora koji su imali u rukama matice iz toga razdoblja, a mi ih danas nemamo. Riječ je ipak o samo nekim župama, prije svega o Brotnju i Veljacima koje do danas imaju sačuvane matice iz toga razdoblja, kao i o Mostaru i Blatu (Širokom Brijegu) koje su obrađene u literaturi. Za ostale župe nema ni takvih podataka.

Najviše podataka sadrži Matica umrlih župe Brotnjo koja je u to vrijeme obuhvaćala ogroman prostor i, kako zapisa fra Petar Bakula, po tome je više sličila na neku manju biskupiju nego na župu: ${ }^{34}$ obuhvaćala je prostor današnjih općina Čitluk i Čapljina s desne strane Neretve, kao i Kruševo i Zviroviće, ili pak današnje župe: Gradnići, Čitluk, Čerin, Međugorje, Gradina (Blizanci), Tepčići-Slipčići, Kruševo, Gabela, Čapljina, GoricaStruge i Gabela Polje te sela Zviroviće, danas dio župe Studenci, i Lipno, danas dio župe Grljevići. ${ }^{35}$

Kuga u broćanskoj župi započela je u lipnju 1814., a prestala u ožujku 1816. godine. U tom razdoblju od gotovo dvije godine u matičnu knjigu nije upisan nijedan pokojnik kojemu uzrok smrti ne bi bila kuga. A tijekom navedenoga razdoblja kuga je uzela čak 2215 života, što je činilo gotovo polovicu župe. Radi se o takvom uništenju župe kakvo nije zabilježeno u povijesti, ne samo u maticama nego u bilo kakvim drugim dokumentima, a vjerojatno da i nije postojalo ništa slično stravičnoj sverazarajućoj kugi iz sredine drugoga desetljeća 19. stoljeća. Prema popisu biskupa fra Augustina Miletića u župi Brotnjo živjela su neposredno prije početka kuge, 1813. godine, 4904 katolička stanovnika (drugih uglavnom nije bilo, ni onda ni sada), što znači da je kuga usmrtila 45,2 \% župljana! Iskorijenjene su čitave obitelji, štoviše i zaseoci, a i neka su sela dovedena gotovo na rub nestanka. Tako je postotak broćanskih katolika stradalih od kuge u skladu $s$ postotkom čitave Bosne i Hercegovine: na tom je području prije kuge (1813.) živio 114.391 katolik, a po svršetku kuge (1818.) broj se smanjio na 50.928 duša, što znači da

33 L. Petrović, "Katoličko stanovništvo u Mostaru", str. 126-127.

34 P. BAKula, Šematizam iz 1867., str. 85.

35 R. Jolić, Stanovništvo Brotnja u tursko doba, str. 5-6, 54-57. 
je iskorijenjeno više od polovice katolika. Druge vjere prošle su još gore, ali o tome nema potanjih podataka.

Prvi slučaj u broćanskoj župi zabilježen je u selu Bijakovićima 3. lipnja 1814., kada je preminuo 27-godišnji Stipan Vlaićević. U istome selu potom su upisane još 22 osobe $s$ istim uzrokom smrti (a peste), a potom slijede i druga broćanska sela. Posljednji slučaj smrti od kuge zabilježen je 5. ožujka 1816. u selu Lipnu, gdje je preminula dvogodišnja Kata Pehar iz Čitluka. Ovdje donosimo podatke po pojedinim selima:

U Gradnićima, gdje je bilo sjedište župe, smrtonosna je zaraza odnijela 42 života od studenoga 1814. do prosinca 1815. Navodimo i ostala sela abecednim redom:

Bijakovići 69 osoba, od lipnja 1814. do svibnja 1815.

Biletići 42 osobe, od srpnja 1814. do prosinca 1815.

Blatnica 32 osobe, od kolovoza 1814. do studenoga 1815.

Blizanci 99 osoba, od listopada 1814. do prosinca 1815.

Čalići 50 osoba, od srpnja 1814. do prosinca 1815.

Čapljina 142 osobe, od srpnja 1814. do lipnja 1815.

Čitluk (s Padalovinom i Žurnjem) 251 osoba, od srpnja 1814. do ožujka 1816.

Čule 36 osoba, od prosinca 1814. do rujna 1815 .

Dobro Selo 101 osoba, od kolovoza 1814. do prosinca 1815.

Dragićina 21 osoba, od lipnja 1814. do lipnja 1815.
Dretelj 61 osoba, od ožujka do listopada 1815.

Gabela 77 osoba, od srpnja 1814. do listopada 1815.

Gradac (Krehin) 87 osoba, od studenoga 1814. do prosinca 1815.

Hamzići 72 osobe, od lipnja 1814. do siječnja 1816.

Krivodo 96 osoba, od lipnja 1814. do studenoga 1815.

Krućevići 114 osoba, od srpnja 1814. do prosinca 1815.

Međugorje 72 osobe, od lipnja 1814. do studenoga 1815.

Ograđenik 167 osoba, od lipnja 1814. do studenoga 1815.

Paoča 48 osoba, od lipnja do kolovoza 1815.

Podgorje 10 osoba, od prosinca 1814. do rujna 1815.

Selište 21 osoba, od rujna do listopada 1815 .

Slipčići 102 osobe, od kolovoza do studenoga 1815.

Služanj 53 osobe, od lipnja 1814. do studenoga 1815.

Sritnice 26 osoba, od prosinca 1814. do rujna 1815 .

Šurmanci 60 osoba, od lipnja 1814. do kolovoza 1815.

Tepčići 93 osobe, od rujna 1814. do studenoga 1815.

Vidovići 59 osoba, od prosinca 1814. do rujna 1815.

Vionica 56 osoba, od rujna 1814. do studenoga 1815. 
Zvirovići 56 osoba, od veljače do prosinca 1815.

Teško je za svako selo navesti i postotak stradaloga stanovništva jer je biskup Miletić na žalost u svome popisu iz 1813. broj stanovnika selâ bilježio skupno (primjerice, Krućevići i Šurmanci 174 osobe), pa se ne zna koliko je stanovnika bilo u svakom pojedinom selu. Svakako, najgore je prošla Čapljina, tada selo s malim brojem katolika, a potom Krućevići i Šurmanci: u svim trima selima broj pomorenih od kuge prelazio je $80 \%$. Najmanje je žrtava kuga uzela u selima Sritnice, Podgorje i Blatnica, manje od $20 \%$.

U maticama se navode i mjesta pokopa: osim seoskih grobalja mrtvaci su pokopavani i u šumama, ogradama, na livadama i uz njive, svakako tamo gdje je tko ispustio dušu. Tako možemo vidjeti da su živi, uza sve opasnosti, ipak nastojali svoje pokojne dolično pokopati. Također se iz matica može išćitati da je većina odraslih osoba prije smrti bila opremljena svetim sakramentima, što znači da su svećenici franjevci, župnici i kapelani, gotovo neprestano bili na terenu pohađajući okužene i dijeleći im svete sakramente umirućih. Pravo je čudo da se nijedan od svećenika i sam nije zarazio i podlegao kugi. ${ }^{36}$

Možemo s pravom pretpostaviti da su broćanski svećenici ubilježili sve potrebne podatke o svima onima čije je živote odnijela strašna kuga koja je harala u župi gotovo dvije godine. Takva marljivost u bilježenju podataka omogućila nam je danas, nakon 200 godina, da možemo u najvećoj mjeri rekonstruirati događanja vezana za kugu na tome prostoru.

$\mathrm{Na}$ žalost, nisu i svi drugi župnici bili tako marljivi i precizni, kako u dijeljenju sakramenata okuženima, tako u upisivanju podataka u matične knjige, što možemo vidjeti na primjeru barem dviju župa: Veljaka i Mostara.

Župa Veljaci u vrijeme kuge obuhvaćala je prostor današnje općine Ljubuški (osim Grljevića), dakle današnje župe Veljaci, Humac, Studenci (osim Zvirovića), Vitina, Klobuk i Šipovača-Vojnići. Izgleda gotovo nevjerojatno da je u župi od kuge preminulo samo 297 osoba, što bi značilo čak 7,5 puta manje nego u susjednoj župi Brotnjo. Prema popisu biskupa Miletića iz 1813. godine župa je imala 2243 katolika, pa je dakle od kuge stradalo 13,2 \% župljana (što je opet gotovo 4 puta manje od broćanskih, gdje je stradalo 45,2 \%). Jasno je da podatci nisu potpuni, točnije da se župnik fra Luka Penava nije potrudio kao broćanski franjevci da bi popisao sve podatke u matičnu knjigu. Osobito je znakovito da u nekim selima ljubuške župe kuga uopće nije zabilježena, tako u Podljubuškom (Humcu), Radišićima, Crvenom Grmu, Klobuku, Šipovači, Vojnićima. Prema novom popisu biskupa Miletića iz 1818. godine može se, istina, također zaključiti da broj smrtno stradalih nije bio visok kao u Brotnju: sada je u župi 2241 vjernik, dakle otprilike kao i u prethodnom popisu iz 1813. godine. Kako je u međuvremenu u župi rođeno 543 djece, a najveći broj je umro od kuge, možemo zaključi-

36 Svi podatci prema: R. Jolić, Stanovništvo Brotnja u tursko doba, str. 289-291. Usp. Isti, "Kuga i kužna groblja u međugorskoj župi", str. 23-24. 
ti da je stvarni broj umrlih od kuge iznosio oko 500, a ne oko 300, kako je zabilježio župnik fra Luka. I sam biskup Miletić bio je razočaran što su brojni umrli neopremljeni sakramentima, što je i upisao u Maticu umrlih prilikom službenoga pohoda župi 6 . srpnja 1818. U svakom slučaju, kuga je ljubuški kraj zahvatila u puno manjoj mjeri negoli broćanski.

Slijede podatci po pojedinim selima veljačke ili ljubuške župe:

Bijača: 12 osoba (svi 1815. godine)

Hardomilje: 16 osoba (svi 1814. godine)

Otok: 17 osoba (svi 1815. godine)

Proboj: 55 osoba (od čega 53 u 1814. godini, a dvoje 1817. godine)

Studenci: 46 osoba (od čega 7 u 1814. godini, 36 u 1816. godini, a troje 1818. godine)

Vašarovići: 27 osoba (svi 1814. godine)

Veljaci: 37 osoba (svi 1814. godine)

Vitaljina: 34 osobe (od čega 29 u 1816., a pet 1818. godine)

Vitina: 48 osoba (od čega 28 u 1814. godini, a 20 u 1815. godini)

Zvirići: pet osoba (od čega dvoje 1815., a troje 1817. godine). ${ }^{37}$

Neka sela uistinu nisu niti bila zahvaćena kugom. Tako iz jednoga izvora saznajemo da u Klobuku, selu koje se tada nalazilo na brdu, a ne ispod njega kao danas, kuge nije bilo te da su zbog toga brojni dolazili izdale- ka ne bi li se spasili. O tome je krajem 19. stoljeća zabilježio fra Martin Mikulić, na temelju pričanja gotovo 90-godišnjeg "djevca" Ivana Jurčića: "Pamtim bič božji - kugu, koja je tri godine svijet davila i morila. Valjalo je po gori bijegati i uvijek se premiještati, da gdje omrkneš, tu ne osvaneš. Mnoge su mrtvace psi izjeli, jer ih nije imao tko ukopati. Za kugom je nastao veliki glad, te smo morali o travi živjeti, kozlac u mlijeku variti, kljenovu koru tući i jesti. Čudno je, da ove kuge nije bilo u ljubuškom Klobuku, koji je pun bio Ljubušana i Mostarana, kao šipak zrnja! Bit će, da su bile u onom selu nekakove velike čudotvorne moći od pomoći." 38

Kolika je panika zavladala ljubuškim krajem možda ponajbolje svjedoči činjenica da su pokojnici ostajali nepokopani te su ležali na cestama ili u ogradama gdje su preminuli. A pokopati ih se moralo koliko god to bilo opasno za one koji su obavljali taj posao, da se zaraza ne bi širila dalje, ali i da mrtvace ne bi razvlačile životinje. $\mathrm{Pa}$ ipak neke nisu uspjeli pokopati prije nego su ih dohvatile. Tako je za pet osoba iz obitelji Grizelj iz Vitine župnik izrijekom zabilježio da su ih "pojeli psi" (devoratus/devorata a canibus). Svi su preminuli 1814. godine i zapisani su u maticu među prvim žrtvama velike kuge. ${ }^{39}$

Dvije naprijed spomenute župe jedine su u zapadnom dijelu Hercegovine čije su matične knjige iz navedenoga

37 Svi podatci prema: Robert Jolıć, "Zarazne bolesti u ljubuškoj krajini u tursko doba. U prigodi 200. obljetnice početka najveće ikad zabilježene kuge u Hercegovini (1814.2014.)", u: Hercegovina franciscana, br. 10, Mostar, 2014., str. 122-129.

38 M. Mikulić, Pustinjakove pripovijetke, str. 35.

39 R. Jolıć, "Zarazne bolesti u ljubuškoj krajini u tursko doba", str. 129. 
razdoblja sačuvane do danas pa podatke o stradalima od kuge možemo crpiti iz njih. Srećom, ipak možemo donijeti podatke, pa makar i sumarne, i za još dvije župe: Mostar i Blato, jer su ih obrađivali neki autori dok su matice još bile sačuvane.

Prilično čudan podatak o župi Mostar donosi dr. fra Leo Petrović navodeći kako je od kuge 1814./1815. godine umrla "371 odrasla osoba", kao da ima neke razlike između odraslih osoba i djece stradalih od kuge, ili kao da su samo jedni od njih upisivani u maticu, a drugi ne. Vidjet ćemo uskoro da tomu nije tako. Važnija nam je napomena istoga autora da je biskup Miletić u istu maticu upisao (dakako latinskim jezikom): "Ustanovili smo, da mnogi, koji su umrli, nijesu upisani." ${ }^{40}$ Uistinu bi broj od 371 katolika stradaloga od kuge u tako velikoj i prostranoj župi kakav je bio Mostar izgledao nestvarno mali. Naime, župa Mostar (sa sjedištem u Mostarskom Gracu) u to je vrijeme obuhvaćala golem i nerijetko nepristupačan prostor mostarske kotline i planina oko Mostara, točnije današnjih župa Mostar (sedam župa u gradu i prigradskim naseljima), Mostarski Gradac, Goranci, Blagaj, Bijelo Polje, dok je selo Grabovica danas u župi Drežnica, a sela Lise i Knešpolje u župi Široki Brijeg. U župi Mostar 1813. godine bilo je 2913 katolika $^{41}$ pa bi, prema Petrovićevu podatku, postotak umrlih od kuge iznosio $12,7 \%$ (otprilike isto kao i u župi Veljaci). Pa ipak drugi autor, vjerojatno prof. fra Vojislav Mikulić, na temelju istih matica donosi ponešto drukčije rezultate. On je matice pregledao temeljitije i donio iscrpnije podatke.

Prvi zabilježeni slučaj kuge potječe iz lipnja 1814., a posljednji iz siječnja 1818. godine, s tim da tijekom 1816. i 1817. nije upisan ni jedan slučaj. Tako je tijekom 18 mjeseci 1814./1815. preminulo od kuge 669 osoba, te još $8 \mathrm{u}$ siječnju 1818., sveukupno 677 osoba. "Da li samo toliko?" - pita se autor i znakovito odgovara: "Kad se uzme u obzir, da i dandanas, uza svu strogost crkvenih i državnih propisa, ima slučajeva, da se umrli ne izpiše, onda je sigurno u to vrieme bilo tih slučajeva mnogo više. Jer onda se nije znalo za smrtni list, podpore i penzije. A ni svećenik nije imao ureda ni pisaćeg stola, nije imao uredovnog ni dana, a kamo li sata. Pojavio bi se od vremena do vremena u mjestu, rekao misu, ispovjedio čeljad pa ured u bisage i dalje. A bilo je slučajeva, gdje bi ciela obitelj izumrla - u Knežpolju u Misira otac, mati i 4 djece isti dan - pa i cielo pleme i mahala, pa nije imao tko ni prijaviti. Kad se sve ovo uzme u obzir, onda možemo mirne duše reći, da ih je umrlo, ako ne dva puta više nego je zavedeno, a ono svakako mnogo više nego je uvedeno." ${ }^{42} \mathrm{~Pa}$ i ako bi broj od 677 osoba bio točan, to bi iznosilo $23,2 \%$ od ukupnoga broja stanovnika, što je dvostruko više od naprijed navedenih Petrovićevih $12,7 \%$. Vjerujem ipak da je kuga pomorila između $30 \%$ i

40 L. Petrović, "Katoličko stanovništvo u Mostaru", str. 127.

41 Dragutin Kamber, "Stanje župa i duša apostolskog vikarijata u Bosni srebreničko-otomanskoj prema popisu izvršenom 1813.", u: Franjevački vijesnik, Beograd, br. 3/1932., str. 87.

42 VE-EM, "Kuga u mostarskoj župi godine 1814-15", str. 55-56. 
40 \% stanovništva mostarske župe, ali brojni pokojnici nisu upisani.

Autor donosi i neke druge detalje, primjerice u kojem je mjesecu umrlo koliko župljana u pojedinim selima. Kuga je počela kositi 1. lipnja 1814. u Mostarskom Gracu (I. Ćavar), a u istome se mjesecu proširila i na Knešpolje, Gorance, Cim, Mostar i Miljkoviće. U sljedećem mjesecu zahvaća Rašku Goru, u kolovozu Lise, u rujnu Jesenicu i Iliće, u listopadu Polog. Do studenoga je već umrlo 100 osoba. U mjesecima sljedeće 1815. godine hara po svim mjestima, ali se smiruje do kraja studenoga: od prosinca 1815. do siječnja 1818. nije upisan ni jedan slučaj. U siječnju 1818. umrlo je 8 osoba, i to svi u Prigrađanima, iz obitelji Matić, čini se svi iz jedne kuće. ${ }^{43}$

Isti je autor [V. Mikulić] donio podatke i za župu (Mostarsko) Blato (od 1847. Široki Brijeg), koja je obuhvaćala otprilike prostor današnje općine Široki Brijeg, ili današnje župe Siroki Brijeg, Kočerin, Rasno, Buhovo, Ljuti Dolac, Izbično, Crnač i veći dio župa Ledinac i Grljevići. Prvi slučaj kuge zabilježen je u Dobrkovićima 4. lipnja 1814. Čini se zapravo da se kuga već krajem svibnja pojavila u Biogracima, ali nije izrijekom navedeno da je riječ o kugi. U lipnju se javlja i u Jarama i Ljutom Docu; u navedena četiri sela ona se javlja kroz cijelo vrijeme dok nije prestala. Jedan slučaj zabilježen je i u Kočerinu. Pod kraj godine kuga hara i u Crnču, gdje je pokosila osobito obitelj Naletilić, i u Pribinovićima.
U veljači 1815. širi se na Jare i Buhovo, u kojem hara 4 mjeseca. U ožujku se javlja u Mokrom, u travnju u Dužicama, u svibnju na Čerigaju, u lipnju na Ledincu, gdje u dva tjedna umire 21 osoba iz obitelji Leko, a u rujnu u Turčinovićima te u prosincu na Medvidovićima. Prestaje u siječnju 1816., iako se i u mjesecima koji slijede pojavljuje tu i tamo pokoji slučaj, sve do travnja 1817. Najviše je od kuge stradalo selo Ljuti Dolac s 82 smrtna slučaja; slijede Biograci 37, Dobrkovići 36, Ledinac 29, Buhovo 21, Crnač 18, Uzarići 15 slučajeva. Najteže je pak stradalo pleme Leka iz Ledinca s 28 umrlih, a slijede Sabljići iz Buhova s 15, Tadići iz Ljutoga Doca s 12 i Damjanovići iz Biograca s 9 umrlih. Ukupno su u maticu ubilježena 294 slučaja smrti od kuge. Autor i ovdje ne vjeruje da su upisani svi preminuli: "Kao diete slušao sam od pokojnog djeda, koji je rođen 1820 , strahote o kugi iz ovog dokaza eto u maticam je u Kočerinu zabilježen samo jedan slučaj. Kako se bilježilo vidi se i iz toga što su na pr. 4 Kraljevića iz Mokrog zavedeni jedan za drugim, iako je jedan umro $\mathrm{u}$ četvrtom, jedan u petom, jedan u sedmom i jedan u osmom mjesecu." ${ }^{14}$ Župa Blato imala je 1813. godine 3908 katolička stanovnika, ${ }^{45}$ što bi značilo da je od kuge umrlo samo 7,5 \% stanovnika. Kako to izgleda nemoguće, možemo zaključiti da je u maticu upisan tek jedan dio stvarno umrlih od navedene pošasti.

Za preostale hercegovačke župe: Duvno, Posušje, Ružići, Konjic nemamo

43 Isto, str. 55.

44 "Kuga u širokobrieškoj župi godine 1814-15.", str. 105-106.

45 D. Kamber, "Stanje župa i duša apostolskog vikarijata u Bosni", str. 87-88. 
ne samo sačuvanih matica, nego niti podataka u literaturi o navedenoj velikoj kugi. Šteta je da je kraj rata 1944. i prestanak izlaženja mostarske Kršćanske obitelji spriječio fra Vojislava Mikulića da objavi podatke o kugi i iz drugih župa, kako je bio najavio. Tako ni mi na ovu temu ne možemo reći ništa više jer nema nikakvih izvora za dovršetak istraživanja.

Pokušajmo na kraju iznijeti podatke za čitavi zapadni dio Hercegovine, i to na temelju spomenutih dvaju popisa koje je načinio biskup Miletić 1813. i 1818. godine, ${ }^{46}$ dakle neposredno prije i poslije kuge. Ti podatci, makar se u njima ne spominje kuga niti broj onih koji su umrli od kuge, nego ukupan broj rođenih i umrlih, ipak nam može pružiti nekakvu okvirnu sliku stanja u zapadno-hercegovačkim župama, ali i ponuditi barem neke naznake o tome koliko je stvarno bilo umrlih od kuge, ili pak koliko su ih župnici propustili upisati u župne matice.

Broj katolika u pet godina manji je za 4005, što jasno pokazuje da je kuga u Hercegovini ipak bila neusporedivo slabijega intenziteta nego u Bosni. K tome, prema prikazanim podatcima ona u župama Ljubuški, a pogotovo Posušje i Ružići, nije bila ni približno razorna kao, primjerice, u župama Mostar, Duvno i pogotovo Brotnjo. Osim toga na prvi se pogled opaža da je natalitet, unatoč svemu, trajno u svim župama bio iznimno velik, što je dakako uvelike amortiziralo razorne učinke kuge. Ono što je znakovito jest da je prirodni priraštaj tijekom navedenih pet godina, između popisa 1813 . i 1818. godine, samo 1362 u "minusu", što je za trećinu manje od ukupnoga manjka stanovništva (4005). Taj se nesrazmjer može protumačiti samo na

\begin{tabular}{|l|l|l|l|l|l|l|l|}
\hline \multirow{2}{\text{Župa}}{} & $\begin{array}{l}\text { Duša } \\
1813 . \text { god. }\end{array}$ & $\begin{array}{l}\text { Duša } \\
1818 . \text { god. }\end{array}$ & Razlika & $\begin{array}{l}\text { Krštenih } \\
1813 .-1818 .\end{array}$ & $\begin{array}{l}\text { Umrlih } \\
1813 .-1818 .\end{array}$ & $\begin{array}{l}\text { Prirodni } \\
\text { priraštaj }\end{array}$ & $\begin{array}{l}\text { Krizmanih } \\
1813 .-1818 .\end{array}$ \\
\hline Duvno & 4576 & 3357 & -1219 & 898 & 1262 & -364 & 475 \\
\hline Roško Polje & 2104 & 1861 & -243 & 329 & 335 & -6 & 314 \\
\hline Mostar & 2913 & 2293 & -620 & 501 & 735 & -234 & 325 \\
\hline Mostarkko Blato & 3908 & 3627 & -281 & 593 & 475 & 118 & 406 \\
\hline Brotnjo & 4904 & 2540 & -2364 & 752 & 2373 & -1621 & 533 \\
\hline Ljubuški & 2243 & 2241 & -2 & 543 & 361 & 182 & 451 \\
\hline Ružići & 1380 & 1880 & 500 & 322 & 145 & 177 & 337 \\
\hline Posušje & 2200 & 2424 & 224 & 558 & 168 & 390 & 482 \\
\hline Polja (kapelanija) & - & - & - & - & - & - & - \\
\hline Ukupno & 24.228 & 20.223 & -4005 & 4496 & 5858 & -1362 & 3323 \\
\hline
\end{tabular}

Napomena: U tabelarnom prikazu nema Konjica jer se u popisu iz 1818. ne navodi kao samostalna kapelanija ili župa, nego je vjerojatno prikazan u sklopu župe Kreševo.

46 Podatci za 1813. godinu prema: Dragutin Kamber, "Stanje župa i duša apostolskog vikarijata u Bosni srebreničko-otomanskoj prema popisu izvršenom 1813.", str. 57, 8688, 112-113; podatci za 1818. godinu prema: BorIs JAKov BARUn, Dušobrižnički rad biskupa fra Augustina Miletića (1763.-1831.), Matica hrvatska, Umag, 1998., str. 192-193. 
dva načina: ili je stanovništvo bježalo u druga područja, izvan Hercegovine, ili su župnici "zaboravili" upisati velik broj stradalih od kuge - kao što i sugerira biskup Miletić u primjedbama na neke župne matice prigodom pastoralnoga pohoda 1818. godine.

Ukupan broj svih umrlih u Hercegovini tijekom pet godina, od 1813 . do 1818., iznosi, prema zbroju svih upisanih u sve matične knjige, koji je preuzeo biskup Miletić - 5858 osoba. Dobar dio njih, ako ne i najveći, umro je od kuge. Smatramo da velik broj njih nije upisan u matice umrlih, a da jest, onaj manjak u prirodnom priraštaju (-1362) zacijelo bi se puno više primakao manjku u ukupnom broju stanovnika (-4005), pa bi ukupan broj umrlih od 1813. do 1818. bio između 8000 i 9000 duša, pri čemu bi od same kuge u zapadnom dijelu Hercegovine stradalo između $6000 \mathrm{i}$ 7000 katolika. Dakako da će to biti teško ikada dokazati.

\subsection{Kolera}

Otkako je 1818. kuga konačno prestala u Hercegovini, ona se više tijekom gotovo već 200 godina ne pojavljuje u maticama. Ali to nipošto ne znači da nije bilo drugih zaraznih bolesti koje su s vremena na vrijeme ugonile strah u kosti cjelokupnom stanovništvu gdje su se pojavile. Kako iz navedenih razdoblja imamo i više sačuvanih matičnih knjiga, to ćemo o tim zarazama moći reći nešto više i donijeti potpunije podatke nego li za dvije kuge koje su naprijed obrađene.
Kolera je bolest koju uzrokuje onečišćena voda što dovodi do crijevne infekcije. Dakako da ne treba čuditi kako se pojavljivala u našim krajevima u kojima nije bilo niti temeljnih higijenskih uvjeta za život stanovništva. U Hercegovini se kolera pojavila barem u trima godinama: 1835., 1855. i 1866. i zahvatila velik broj župa i sela, barem koliko se može istražiti na temelju sačuvanih matičnih knjiga. $\mathrm{O}$ onim župama čije matice nisu sačuvane u tom razdoblju dakako da ne možemo donijeti nikakvih podataka.

Prvi slučaj kolere u broćanskoj župi zabilježen je 8. listopada 1836., kada je preminuo 56-godišnji Jozo Primorac iz Čitluka. Umro je i pokopan negdje "preko Neretve". Potom je u listopadu i studenom preminulo u istoj župi još 14 osoba od iste bolesti - ukupno 15. Mjesta smrti: Čitluk (1), Žuranj (1), Gabela (5), Tepčići (1), Blizanci (1) i Slipčići (6). ${ }^{47}$ Te godine se kolera nije pojavila u ljubuškoj krajini, barem sudeći prema maticama. Ali jest u mostarskoj župi: zabilježena su tri slučaja, u trećoj trećini studenoga 1836.: dva u Donjem Gracu i jedan u Lisama (danas sva sela u širokobriješkoj općini).$^{48}$ Prema matici zaraza se nije širila dalje.

U duvanjskoj župi zabilježeno je da se kolera u prosincu 1836. pojavila u selu Borčanima te usmrtila trojicu braće Matića, njihove žene i djecu, ukupno osam mrtvih. Svi su pokopani 20. prosinca na groblju Radoševina. U drugim selima te godine nije upisan ni jedan takav slučaj. ${ }^{49}$

49 R. Jolić, Život i smrt u Duvnu, str. 85. 
Ostale zapadno-hercegovačke župe nemaju tako stare sačuvane matice da bismo mogli istražiti je li se te godine kolera pojavili i u drugim krajevima. Ali zato je o koleri, koja je počela harati 1855 . godine, ostalo više pisanih tragova.

U broćanskoj župi od kolere 1855. preminule su 22 osobe. Prvi je slučaj zabilježen u Gradnićima u listopadu 1855. kada je preminuo 20-godišnji Jure Zubac Pavlov. Mjesta smrti: Gradnići (5), Hamzići (4), Bijakovići (2), Dobro Selo (2), Odaci (1), Ograđenik (5), Gradac (1) i Slipčići (1). Kolera je uzimala živote bez obzira na dob, od dvogodišnje djece do 85-godišnjih staraca. ${ }^{50}$

U veljačkoj župi broj je stradalih od kolere iste godine bio trostruko veći: bolest je u samo jednoj godini usmrtila 65 osoba, i to bez istočnoga dijela ljubuške krajine, jer se u međuvremenu (1855.) od matične župe Veljaka odcijepila kapelanija Humac, ali župnik sve do sredine 1856. nije u maticu umrlih upisao ni jedan jedini podatak. Najviše je osoba umrlo od kolere u Vitini (21), a slijede Klobuk (14), Grab (10), Veljaci (8), Vašarovići (4), Grabovnik (3), Dole (2), Otok (2) i Šiljevišta (1). Najmlađa preminula osoba bio je tromjesečni Ante Markotić iz Graba, a dvije najstarije 105-godišnji Petar Grizelj iz Vitine i 97-godišnji Jure Mihaljević iz Graba (dakako, ako su njihove godine ispravno upisane!). Zadnji slučaj ubilježen je na Božić 1855 . godine. ${ }^{51}$

Iste su godine u duvanjskoj župi zabilježena samo tri takva slučaja: po jedan u Brišniku, Lipi (osoba preminula u blizini Ljubuškoga) i Seonici. ${ }^{52}$ I u župi Ružići ubilježena su samo tri slučaja kolere 1855 . godine: dva u Tihaljini i jedan u Drinovcima. Riječ je o dvojici mladića od 20 godina i jednoj starici od 70 godina..$^{53}$

U župi Mostarski Gradac bilo je više smrtnih slučajeva, ukupno 12 , od sredine listopada do kraja prve trećine studenoga 1855. Polovica od toga bilo je u Knešpolju (danas općina Široki Brijeg), a ostali u Vrdima (3), Đubranima (1), Pologu (1), dok je jedna osoba preminula u Proboju kod Ljubuškoga i tamo pokopana. Najmlađi je dječak od 3 godine, a najstarija starica od 78 godina, ali je redovito riječ o osobama između 20 i 50 godina. Zanimljivo je da bolest nije u potpunosti nestala, nego se ponovno pojavila nakon godinu i pol dana: 10. ožujka 1857. u Podivačju (Raška Gora) preminuo je 28-godišnji Bože Pandža, a potom još 11 osoba do sredine lipnja iste godina, u dobi od 14 do 54 godine. Mjesta smrti: Grabova Draga (4), Vlasnići (4), Đubrani (2) i Raška Gora (1), dakle sve u brdima u kojima su živjeli hercegovački stočari. Tako su 1855. i 1857. godine u župi Mostarski Gradac preminule ukupno 24 osobe kojima se kao uzrok smrti navodi kolera. ${ }^{54} \mathrm{U}$

50 R. Jolić, Stanovništvo Brotnja u tursko doba, str. 292.

51 R. Jolić, "Zarazne bolesti u ljubuškoj krajini u tursko doba", str. 129-130.

52 R. Jolić, Život i smrt u Duvnu, str. 85-86.

53 Matica umrlih Ružići, sv. I., str. 50, br. 70-72.

54 Matica umrlih Mostarski Gradac, sv. I., str. 110-117. 
župi Mostar, koja se 1849. odijelila od Mostarskoga Graca i obuhvaća uglavnom dolinu Neretve (za razliku od M. Graca, kojemu su uglavnom preostala planinska područja bivše jedinstvene župe), stanje je bilo još gore: od kraja rujna do kraja studenoga 1855. u župi je od kolere preminula 41 osoba, od čega daleko najviše u samome gradu Mostaru - 35 osoba. Ostala naselja: Sovići (3), Raštani (1), Ilići (1), Jasenica (1). Prva je preminula 80-godišnja Kata Zelenika iz Mostara 29. rujna 1855., a potom su umirala kako djeca od 3 godine, tako starci i starice od 60 ili 70 godine, međutim daleko najviše krjepkih muškaraca i žena između $20 \mathrm{i}$ 50 godina. ${ }^{55}$ Župnik mostarski načinio je zapravo odvojeni popis umrlih od kolere naglašavajući da je svoja "usta otvorila" upravo u gradu Mostaru te da je "proždrla" 38 katolika, 150 pravoslavnih, 280 muslimana, 18 cigana i 2 Židova - makar za ostale vjere nije u potpunosti siguran, budući da oni nemaju matičnih knjiga. ${ }^{56}$ Čini se da se kolera po čitavoj Hercegovini proširila upravo iz Mostara.

Konačno možemo saznati je li bilo kakve zarazne bolesti i u konjičkom kraju jer župa čuva matične knjige počevši od 1837. godine. Matica umrlih međutim ne bilježi koleru ne samo 1855., nego ni jedan jedini slučaj u 19. stoljeću, niti uopće. Župa Posušje pak ne posjeduje Maticu umrlih sve do 1928. godine pa nam o starijim razdobljima ne može dati nikakav podatak. Matica umrlih župe Gorica-Sovići, koja se 1839. odcijepila od matične župe Posušje, bilježi samo jedan slučaj smrti od kolere: 17. studenoga 1855. preminuo je naime 45-godišnji Bernard Spajić iz Gruda, opremljen sakramentima, te pokopan na mjesnom groblju. ${ }^{57}$

Iste se godine kolera (pučki nazvana kratelj) pojavila i u Bosni, osobito u Sarajevu, Kreševu, Fojnici i Livnu, a bilo je i u Travniku. O njoj piše ljetopisac fra Jako Baltić, koji se i sam bio otrovao, ali je ipak preživio. On navodi da su se ljudi trovali jedući voće i krastavce, iako to danas ne izgleda odveć vjerojatnim. Mnogi su se, nastavlja Baltić, razboljeli od samoga straha: "Kad bi se reklo, ovi se razbolio, nika čeljad odmah bi se pripala i razbolila." Ni to ne izgleda vjerojatnim. Župa Guča Gora odlučila je kupiti jednu misnicu (paramentu), koju su dobavili iz Beča, pa kolere u župi gotovo da nije bilo. Od nje je u Cukliću kod Livna preminuo i fra Petar Križanac, rodom iz Vedašića kod Duvna, učen čovjek i uzoran redovnik i svećenik, koji "imadijaše najlipše pismo ovog vrimena u Bosni". ${ }^{8}$

U matičnim knjigama u Hercegovini smrt od kolere pojavljuje se u kasnijim desetljećima samo još u dva slučaja, u

55 Matica umrlih Mostar, sv. I., str. 33-38.

56 Hac in civitate Mandetriensi die 29. Septembris 1855. adaperuit morbus cholericus os suum, devoravitque 38 Christianos Romano-Catholicos; Graecos Schismaticos 150; Mahomedanos 280; Zingaros 18; Israelitas 2. Quod respicit infideles supra dictos mortuos ignoratur certe verus numerus, eo quia desunt protocolla quibus inscribuntur (Matica umrlih Mostar, sv. I., str. 33).

57 Matica umrlih Gorica-Sovići, sv. I., str. 39, br. 53.

58 J. BALtić, Godišnjak, str. 258-259. 
župi Mostarski Gradac, i to na samom kraju listopada 1866. Od kolere su preminula dvojica muškaraca u Donjem Gracu: 55-godišnji Mijo Kopilaš i 27-godišnji Jozo Bakšić. Obojica su opremljena svetim sakramentima i pokopana u mjesnom groblju. ${ }^{59} \mathrm{Upis}$ je svakako pomalo čudan jer je teško zamisliti tako izoliran slučaj zarazne bolesti koji se nije širio niti prostorno niti vremenski. Možda je riječ o pogrješnom upisu uzroka smrti?

\subsection{Boginje (variole)}

Nova smrtonosna zarazna bolest koja nije mimoišla ni Hercegovinu, i to $u$ više navrata, bile su boginje ili variole. Pogađa isključivo ljude, prenosi se zrakom (udahom) te stvara karakterističan osip i bubuljice na koži. Konačno je u svijetu iskorijenjena tek 1979. godine. Velike boginje usmrtile su 300-500 milijuna ljudi u svijetu samo u 20. stoljeću, a vjeruje se da su se pojavile još prije 10.000 godina. $^{60}$

Prvi slučaj u zapadnom dijelu Hercegovine zabilježen je u župi Brotnjo (riječ je dakako o sačuvanim matičnim knjigama) 8. travnja 1798. kada je preminuo 40-godišnji Andrija Erić iz Odaka. To je ujedno i jedini slučaj zabilježen u 18. stoljeću. Pravi pomor uslijedio je samo desetak godina kasnije, 1809. i 1810., kada su u Brotnju od variola preminule 42 osobe. Najviše ih je bilo iz Čitluka (9) te Dobroga Sela i Vidovića (po 5). Među žrtvama su i djeca (dvanaestero do 10. godine života) i starci, ali u najvećem broju odrasli ne stariji od 50 godina. Sljedeći put variole se pojavljuju 1820./1821. godine kada je u broćanskoj župi bilo sedam smrtnih slučajeva, od čega šestero djece, od 12 dana do 7 godina starosti, te jedna 39-godišnja žena. Od srpnja 1839. do lipnja 1840. u istoj su župi variole uzele živote 42 osobe (isto kao i prije 30 godina), od čega 18-ero djece ispod 10 godina života. Najviše je opet muškaraca i žena u najsnažnijoj životnoj dobi, od 20-ih do 50-ih godina života. Bolest se na istome prostoru javljala i kasnije u nekoliko navrata: 1846 . od nje su preminule dvije osobe, kao i 1870 . godine; 1876./1877. preminulo je 10 osoba od variola. Posljednji slučajevi zabilježeni su 1888. godine kad su u Blizancima preminule dvije djevojčice, vjerojatno sestre: 4-godišnja Ana i 7-godišnja Ilka Bevanda, kćeri Antine. ${ }^{61}$

Zanimljivo je da se u Matici umrlih župe Veljaci ne spominje ni jedan slučaj variola. U duvanjskoj je Matici umrlih pak zabilježeno 6 slučajeva smrti od boginja, ali ne u onim godinama kad je ista bolest harala u broćanskoj župi. U listopadu 1834. tako je preminuo Filip Nevistić, a u prosincu iste godine Petar Bernardić, obojica iz sela Omerovići, i obojica 45-godišnjaci. Godine 1836. nova dva slučaja, oba u Mrkodolu: preminule su dvije mlađe udate žene, u 28. i 33. godini života. Posljednja dva slučaja zabilježena su 1858. godine, u Bukovici i Bučićima, a riječ je o dvojici muškaraca u zrelim godinama. ${ }^{62}$

59 Matica umrlih Mostarski Gradac, sv. I., str. 140, br. 233-234.

60 http://hr.wikipedia.org/wiki/Boginje (27. 4. 2015.).

61 R. Jolić, Stanovništvo Brotnja u tursko doba, str. 292-293.

62 R. Jolić, Život i smrt u Duvnu, str. 86. 
U župi Mostarski Gradac zabilježeno je 19 slučajeva variola, ali u četiri različite godine. Najviše ih je bilo 1846., kada je u veljači i ožujku usmrćeno 6 osoba (3 iz grada Mostara, po jedna iz Cima, Knešpolja i Lisa), i 1863./1864. kada je od lipnja 1863. do siječnja 1864. stradalo 10 osoba (4 iz Graca, 4 iz Goranaca te po jedna iz Bogodola i Domazeta). Osim tih godina bolest se pojavljivala i 1852., kada je usmrtila dvije osobe: 65-godišnjega Marka Marića iz Ričine kod Neretve, kojega župnik nije uspio opremiti zbog snijega (veljača) i zabačenosti mjesta, i 35-godišnju Maru Lončar, ženu Franjinu, iz Graca. Posljednji slučaj zabilježen je 25. srpnja 1870., kada je preminuo 25-godišnji Jure Andačić te pokopan na mjesnom groblju u Vlašićíma (valjda Vlasnićima). ${ }^{63}$ Istodobno su u župi Mostar, koja se 1849. odvojila od Graca, zabilježena samo 4 smrtna slučaja kojima su uzrok bile variole, i to svi u gradu Mostaru. Svi su umrli u travnju, svibnju i srpnju 1857. te pokopani na groblju Šoinovac. Riječ je o osobama između 20 i 40 godina života. ${ }^{64}$

U župi Ružići zabilježena su u vrijeme turske vladavine samo 4 slučaja variola, i to u srpnju i kolovozu 1864. Po jedna je osoba preminula od variola u Selinama, Grudama, Drinovcima i Bovanima, od čega troje 35-godišnjaka i jedan 18-godišnjak. Kasnije se bolest opet pojavljuje i uzima 8 života u župi od rujna 1888. do veljače 1889 ., od čega po dvoje u Selinama, Višnici i Ružićima te po jedno u Dragićini i Tihaljini. Četvero je djece, a ostalih osmero od 18 do 52 godine života. Istodobno od rujna 1888. u župi vlada epidemija ospica od kojih je preminulo čak 47 osoba. Župnik bolest naziva ex pustulis malignis ili pustularum morbo, ili pak jednom hrvatski ospice. Otprilike su polovica umrlih bila djeca, a polovica odrasli. Posljednji upis je iz ožujka 1889. Kako se ta bolest poklapa s variolama iz 1888./1889., možemo pretpostaviti da je zapravo riječ o istoj bolesti koja se ponešto različito manifestirala pa ju je župnik upisivao različitim imenima. ${ }^{65}$

U župi Gorica-Sovići bolest se pojavljuje početkom 1852. i sredinom 1877. godine. Ukupno je od nje umrlo 6 osoba, od čega dvoje 1852 . i četvero 1877. godine. Jedan je bio dječak od 8 godina, a ostali od 22 do 60 godina starosti. Svi su opremljeni svetim sakramentima i pokopani na groblje sv. Stjepana u Gorici. ${ }^{66}$

Matice župe Konjic opet ne donose nikakve vijesti niti o variolama. Župa Posušje pak ne posjeduje matice starije od 20. stoljeća.

Variole se razlikuju od kuge i od kolere što se ne prenose na velike udaljenosti pa se tako ne pojavljuju istodobno u više župa, nego redovito ostaju

63 Matica umrlih M. Gradac, sv. I., str. 75-77, 101, 103, 130-132, 148.

64 Matica umrlih Mostar, sv. I., str. 47, 49.

65 Matica umrlih Ružići, sv. I., str. 114, 295-310.

66 Matica umrlih Gorica-Sovići, sv. I., str. 28-29, 165-166. 
izolirane na prostoru jedne župe, štoviše jednoga sela ili pak nekoliko susjednih sela.

\subsection{Ostale zarazne bolesti}

Uz navedene bolesti u matičnim se knjigama ponekad, iako vrlo rijetko, spominju i neke druge, prije svega dizenterija i ospice (koje su već naprijed spomenute u tekstu). Pretpostavljamo da je bilo i drugih bolesti, prije svega tifusa, ali se one uopće ne spominju u maticama. Kao primjer možemo navesti smrt dvojice svećenika, župnika i kapelana, u Mostarskom Gracu: fra Ivana Radmana Zupca i fra Mije Kujundžića. Obojica su preminula istoga dana, 13. travnja 1841. u Gra$\mathrm{cu}$ te pokopana na mjesnom groblju. U Matici umrlih doneseni su njihovi životopisi, ali nema nikakve naznaka o uzroku njihove smrti. ${ }^{67} \mathrm{U}$ franjevačkim nekrologijima pak piše da je uzrok njihove smrti bio tifus, ${ }^{68}$ što je zacijelo istina jer je teško zamisliti da bi dvojica mladih svećenika, kakvi su oni bili, umrla na istome mjestu istoga dana, a da ne bi bila riječ o kakvoj zaraznoj bolesti. Zanimljivo je štoviše da se termin tifusa ne pojavljuje sve do Prvoga svjetskog rata. Jedini slučaj koji smo pronašli u maticama, a stariji je od početka rata, makar i neznatno, potječe iz 1913., kada su u selima ružićke župe Poganoj Vlaki i Selinama zabilježena dva slučaja tifusa. ${ }^{69}$ Dakako, u ratu su zabilježeni brojni slučajevi tifusa, a osobito je stravična bila zaraza španjolske bolesti koja je započela pred kraj rata 1918. i uzela milijune ljudskih života u svijetu, a tako i tisuće u našim krajevima. Bilo bi vrijedno svakako istražiti podatke i o tim dvama bolestima u vrijeme Prvoga svjetskog rata i poraća, ali to će ostati za neku drugu prigodu.

U župi Gorica-Sovići zabilježen je samo jedan slučaj smrti od tifusa (a morbo tipho): 26. srpnja 1876. preminula je 24-godišnja djevojka Lucija Bazina iz Sovića i pokopana na groblju sv. Stjepana u Gorici. ${ }^{70}$

Dizenterija (dissenteria, dyssenteria) je zarazna bolest debeloga crijeva (srdobolja), a pojavljuje se kao posljedica loših higijenskih uvjeta, osobito u ratnim vremenima. Prvi slučaj koji smo uspjeli pronaći u matičnim knjigama potječe iz ožujka 1832. kad je u Slipčićima preminuo 40-godišnji Nikola Blažević. Najviše slučajeva u broćanskoj župi zabilježeno je u studenom 1839., kad je preminulo pet osoba, od čega četvero u Sritnicama i jedna u Međugorju. U Međugorju je i u kolovozu 1846. od dizenterije preminulo šest osoba, najviše djece. U Gabeli i Zvirovićima preminule su od dizenterije tijekom 1887. i 1888. tri osobe, sve mala djeca, u dobi od 7 mjeseci te 2 i 4 godine. $^{71} \mathrm{U}$ župi Ružići zabilježeno je 12 slučajeva smrti od dizenterije (dyssenteria) od rujna do studenoga 1858., a najviše u listopadu. Tada je u Grudama zabilježeno 6 slučajeva, u Ružićima 4

67 Matica umrlih M. Gradac, sv. I., str. 44, br. 124, 125.

68 Usp. Robert Jolić, Leksikon hercegovačkih franjevaca, Mostar, 2012., str. 214, 325.

69 Matica umrlih Ružići, sv. III., str. 22, br. 40, 43.

70 Matica umrlih Gorica-Sovići, sv. I., str. 158, br. 59.

71 R. Jolić, Stanovništvo Brotnja u tursko doba, str. 293-294. 
i u Tihaljini 2. Riječ je uglavnom o djeci u dobi od 4 mjeseca do 7 godina, a samo dvije osobe starije životne dobi, zapravo 71-godišnja starica i 90-godišnji starac. ${ }^{72}$ Izgleda dakle da su najlakše podlijegali ili djeca ili starci koji su bili najneotporniji da bi se organizam mogao sam obračunati s bakterijom. U istoj su župi puno kasnije zabilježena još dva slučaja dizenterije, u Dragićini u rujnu 1889. i u Ružićima u srpnju 1890. U oba slučaja riječ je opet o maloj djeci od jedne i dvije godine života. ${ }^{73}$

U drugim župama nisu zabilježeni slučajevi dizenterije, osim jedan u konjičkoj župi: krajem kolovoza 1881. u Turiji je od te zaraze preminuo 11-godišnji Marko Barać te je pokopan na mjesnom groblju. ${ }^{74}$

Ospice su već ranije spomenute: riječ je redovito o dječjoj bolesti, ali od nje mogu oboljeti sve starosne skupine. Karakteriziraju je Koplikove pjege (na sluznici ždrijela i obraza) i kašalj, preko kojega se i prenose na druge osobe. Po uvođenju obvezatnoga cijepljenja (kod nas od 1968.) u svijetu je uglavnom nestalo ospica. Nazivaju ih i malim boginjama ili morbilima. ${ }^{75}$ Prvi slučaj zabilježen u župi Brotnjo jest smrt 56-godišnje Veronike Brkić iz Hamzića koja je preminula 3. ožujka 1804., a župnik je uz njezinu smrt napisao hrvatskim jezikom: od ospicza, makar je čitava matica pisana latinskim jezikom. Kasnije je u Matici umrlih župe Gabela, koja se 1854 . odcijepila od matične župe Brotnjo, zabilježeno čak 39 slučajeva smrti od ospica u samo jednoj godini, 1888. Najčešće su od bolesti umirala djeca i mladi do 20 godina, ali je zabilježeno i 6 slučajeva smrti osoba starijih od 20 godina: najstarija je žena od 36 godina. ${ }^{76}$

$U$ većini zapadno-hercegovačkih župa ospice se kao uzrok smrti uopće ne spominju (Duvno, Mostar, Rakitno, Ružići, Veljaci, Konjic, Gorica), ali se zato u župi Ružići navodi čak u 47 slučajeva. Prvi put u rujnu 1858. u Blaževićima: od ospica (upisano hrvatskim jezikom!) preminuo je 65godišnji Ivan Grubišić te pokopan na istome groblju. ${ }^{77}$ Ovdje ipak moramo posumnjati da je uistinu bila riječ o ospicama, jer odmah nakon toga upisa slijedi 12 upisa smrti od dizenterije, kao što je već naprijed rečeno, sve u rujnu i listopadu iste godine. Vjerojatno je zapravo i Ivan Grubišić umro od dizenterije a ne od ospica, kako je župniku bilo (pogrješno) javljeno. No za preostalih 46 slučajeva smrti od ospica ne treba ni najmanje sumnjati: svi su naime upisani preminuli od iste bolesti u razdoblju od kraja kolovoza 1888. do početka ožujka 1889. godine.

72 Matica umrlih Ružići, sv. I., str. 67-69, br. 49-70 passim.

73 Matica umrlih Ružići, sv. I., str. 313, br. 183; str. 321, br. 3.

74 Matica umrlih Konjic, sv. I., str. 102, br. 34.

75 http://www.vasezdravlje.com/izdanje/clanak/918/ (28. 4. 2015.).

76 R. Jolić, Stanovništvo Brotnja u tursko doba, str. 294.

77 Matica umrlih Ružići, sv. I., str. 66, br. 44. 


\section{Zaključak}

Čitav je svijet stoljećima, štoviše tisućljećima, strepio od zaraznih bolesti, osobito od kuge, koje su se pojavljivale svako malo i na različitim stranama svijeta te se nerijetko uspješno širile na vrlo široke prostore i kosile sve pred sobom. Neke od tih zaraza postajale su prave epidemije pred kojima nije bilo nikakve obrane, a neke su od njih imale štoviše pendemijske razmjere te su kosile milijune žrtava pred sobom. Danas je najveći broj takvih bolesti koje su imale najrazornije posljedice sve do 19., čak i 20. stoljeća, u potpunosti iskorijenjene iz svijeta, ili barem iz zapadne civilizacije. Došle su pak nove zaraze, kao što je primjerice ebola ili sida, za koju će se lijekovi tek pronaći u budućnosti, a u zaostalijem dijelu svijeta osim novih bolesti zadržale su se i neke stare, a sve to zbog nedostatka temeljnih higijenskih uvjeta življenja, kao i lijekova.

Proučavanje zaraznih bolesti u našim krajevima u vrijeme turske vladavine zacijelo dopunjava sliku ionako sumornoga okruženja u kojem su živjeli katolici: u svakodnevnoj nesigurnosti za goli život, izloženi nesmiljenim i trajnim progonima od turskih vlasti i silnika, i muslimana općenito, redovito na rubu gladi koja je bila trajan pratilac siromašnoga i od svakoga ostavljenog puka. Ako tome dodamo i strašne posljedice zaraznih bolesti, o kojima je ovdje riječ, onda se slika kompletira i čovjek se pita, kako je katolički element uopće opstao na ovim vjetrometinama tijekom četiri otomanska stoljeća.
Zarazne i druge bolesti bile su ipak čimbenik koji je izjednačavao pred zakonom i u praksi potpuno neravnopravne stanovnike, jer kuga je pred sobom kosila jednako i muslimane i kršćane, i ugnjetavače i ugnjetene, i bogate i siromašne, i stare i mlade, i zdrave i krhke, i prosvijećene i nepismene. Barem u tome nije bilo nikakve nepravde.

Možda bi na kraju bilo zgodno vidjeti kako je katolički element uopće uspio preživjeti unatoč tolikim negativnim silnicama koje su ga gurale u potpuni nestanak? Pokušat ćemo to demonstrirati na temelju podataka o župi Brotnjo jer samo o njoj imamo cjelovite rezultate istraživanja, budući da samo ta župa posjeduje dovoljno stare matice (od 1775. godine) koje su sačuvane u kontinuitetu do danas. Barem što se tiče oporavka od kuge i drugih zaraznih bolesti. U Matici umrlih župe Brotnjo od 1775. do 1890. zabilježena su 2424 slučaja umrlih od zaraznih bolesti: 2287 od kuge, 37 od kolere i 110 od boginja. U ukupnom broju umrlih u navedenom razdoblju, koji iznosi 8930 , to je iznimno velik omjer: čak $25,6 \%$, što znači da je svaka četvrta osoba u tih 115 godina umrla od neke zarazne bolesti, najviše od kuge. Uz pretpostavku da ipak nisu upisani svi takvi slučajevi. ${ }^{78}$ A kako je tekao oporavak? Prema popisu biskupa Miletića iz 1813. godine župa Brotnjo imala je 4814 vjernika. Kuga je u dvije godine (1814.-1816.) usmrtila čak 2215 osoba. Prema novom popisu istoga biskupa iz 1818. broj katolika u Brotnju iznosio je 2372, što znači da se

78 R. Jolıć, Stanovništvo Brotnja u tursko doba, str. 294. 
smanjio gotovo za polovicu (47,2 \%). puka u zapadnome dijelu HercegoviAli već u sljedećem popisu iz 1844. ne: kao da kuge nije ni bilo. Ne treba župa Brotnjo imala je 5698 stanovni- ni spominjati da je riječ isključivo o ka, što znači da se župa za samo 26 prirodnom prirastu, temeljenom opet godina (od 1818.) povećala za čak dakako na izvanrednoj stopi natalite3158 stanovnika, a to znači za 2,24 ta. ${ }^{79}$ Danas bi takvo nešto bilo potpuputa ili $124,3 \%$. To je uistinu izvan- no nezamislivo!

redan primjer vitalnosti katoličkoga

79 R. Jolić, Stanovništvo Brotnja u tursko doba, str. 90-91. 


\section{Infectious diseases in Herzegovina during}

the Turkish rule

\section{Summary}

It has long been known that registers provide exceptional data related to demographic trends and changes in the specific area they cover. An increasing number of people, both professionals and amateurs, use them not only for the purpose of drafting family trees, but also to reconstruct the overall life processes of a place or a parish. The same applies to Herzegovina, although there is still plenty of work to do.

In this paper, the author demonstrates the value of data hidden in the registers related to a very specific and selected topic: infectious diseases in the west-Herzegovinian territory during the Ottoman rule. Unfortunately, not all registers from this period have been preserved, moreover only few of them were saved, which makes the data incomplete and insufficient. However, combined with other sources, primarily lists of Catholic population from this period and records of contemporary (Franciscan) annals, there can be found extremely valuable and up to now completely unknown data.

The author gives a particularly detailed analysis of great plague that affected a large part of Europe in 1814, including the area of Herzegovina. In two years the plague killed millions in Europe and halved the Catholic population in Bosnia and Herzegovina. For other religious communities the situation was even worse, but there were no details due to the fact that their registers did not exist. However, it is completely clear that the effects of the plague in Herzegovina were not nearly as devastating as in Bosnia, and some parishes indeed remained spared from it, especially Ruzici and Posusje. The worst situation was in the parish of Brotnjo that lost half of its population, which was in line with the total $\mathrm{BH}$ average.

Apart from plague, the paper, based almost exclusively on preserved registers, analyzes the other infectious diseases, especially choleraand smallpox, and toalesserextent, measlesanddysentery. Only exceptionally high birth rate at the time saved the Catholics from complete extinction. Constant pressure of unbearable persecution and levies from the Turkish authorities and tyrants, regularly on the brink of starvation, with today unimaginable infant mortality rate of probably $50 \%$, and from time to time subjected to devastating plague and other con- 
tagious diseases, they managed to resist only giving birth to offspring. The number of Catholics in the early 18th century had dropped to only 20 thousand, in the early 19th century it rose to almost 120,000, and then the plague between 1814 and 1818, again halved and reduced that number to 50,000. Since then, the population has been constantly growing, despite World War I and what was called Spanish fever, an unprecedented infectious disease that ensued at the end of the war, despite the huge losses in manpower during World War II, and especially after the war, and despite the ongoing migrations which started in the 60s of the 20th century reaching thus its historical peak. Finally, in the Homeland war numerous Catholic Croats were expelled from their homes, particularly in Bosnian Posavina and Krajina and the number again halved in comparison to the 70 s or 80 s of the 20 th century. It is hard to imagine that the number of Catholics will in the near future recover again, as it normally happened in previous centuries. The reason: there is no such birth rate that has been in the previous centuries the strongest bulwark against extinction.

Keywords: Herzegovina, registers of deceased, infectious diseases, plague, smallpox (variola), cholera, dysentery, measles. 